European Journal of Pragmatism and American Philosophy

VII-2 | 2015

John Dewey's Lectures in Social and Political Philosophy (China)

\title{
Lectures in Social and Political Philosophy
}

John Dewey

\section{(2) OpenEdition}

\section{Journals}

Electronic version

URL: http://journals.openedition.org/ejpap/404

DOI: $10.4000 /$ ejpap.404

ISSN: 2036-4091

Publisher

Associazione Pragma

\section{Electronic reference}

John Dewey, «Lectures in Social and Political Philosophy », European Journal of Pragmatism and American Philosophy [Online], VII-2 | 2015, Online since 23 December 2015, connection on 19 April 2019. URL : http://journals.openedition.org/ejpap/404 ; DOI : 10.4000/ejpap.404

This text was automatically generated on 19 April 2019

\section{(c) $(1)$}

Author retains copyright and grants the European Journal of Pragmatism and American Philosophy right of first publication with the work simultaneously licensed under a Creative Commons AttributionNonCommercial-NoDerivatives 4.0 International License. 


\title{
Lectures in Social and Political Philosophy
}

\author{
John Dewey
}

\section{Lecture I [Chapter The Function of Theory, pp. 45-53]}

1 The direct use of language for definite purposes according to the needs of the moment long preceded grammar, rhetoric and the dictionary. Breathing, eating, digesting, seeing and hearing long preceded anatomy and physiology. We first act to meet special needs and particular occasions. Only afterwards do we reflect upon what we do and how and why we do it, and try to frame general principles, a philosophy of the matter. So with social, collective action. Men built up customs and transmitted traditions to their offspring for centuries before they tried to discover any rationale in what they did. They made no attempts at explanation. If asked what for one they would have said they had such and [such] customs because they liked them, or because their ancestors told them so to act or because their gods had established them. To question too closely was to be impious or disloyal, and might result as with Socrates in death.

\section{[End Page 1]}

2 Thinking is naturally hard and obnoxious. It is easier to follow instinct and custom and the orders of others. Men think when forced to do so by trouble by something the matter which makes it necessary to find some way out not provided by habit and inclination. So men began to philosophize about their collective habits, their established institutions only when these began to cease [to] function satisfactorily. The difficulties might be internal strife or external contacts and conflicts or both. But something threatening change or disintegration made men compare and inquire and attempt to select and hold on to the really good. Disease and wounds of battle made men study anatomy and the normal physiological processes. Otherwise men might forever have taken for granted their 
natural processes without thinking of them never directing attention to them. Social pathology had similar effect on social theorizing. Ill from Greece, from China. After theory had once arisen life does not go on just the same. Men do not breathe and eat because of their knowledge of anatomy and physiology. These acts still depend upon deeper forces. But they may eat and breathe somewhat differently, especially in emergencies, because of their knowledge.

\section{[End page 2]}

3 The question may arise however as to what difference ideas, theories, philosophies really make. Do they make a difference in what men do or only in what they feel about what they do. Is philosophizing practical like steam as a driving force in the locomotive? Or is it more like the noise of the escaping steam in the whistle - a by-product, an accompaniment, a symptom of what is going on? There are replies which are highly exaggerated in both directions. Bookish people and philosophers are likely to attach too much importance to abstract ideas, to regard them as the most important moving causes. They seek ideological explanations for everything. They overlook the extent to which men are still driven into action by primary instincts like hunger, sex and love of power or comfort and glory, by the pressure of circumstances and by the ease of paths of habit. They say for example that the last war was primarily and essentially a conflict of philosophies, of systems of ideas. At the other extreme we have the so-called materialistic explanations of institutions and social changes. Economic causes are said to be the only real or dynamic causes. Ideas are effects, products

\section{[End page 3]}

only. Desires first for the primary necessities of life and then for power over others and for enjoyment of the luxuries due to wealth are the only explaining causes. Even art and religion and systems of morality as well as social customs and political regulations are to be explained economically. The war was not a conflict of ideas and ideals but a struggle for economic advantages and commercial supremacy. Ideals, theories are but a mask to conceal the material struggle going on, fine phrases to arouse the multitude that allows themselves to be beguiled by them. Philosophies that pretend to do more than analyze and describe the play of economic forces are only dreams or else devices by which the few powerful maintain their hold upon the masses. We meet here the first great question concerning social philosophy - one which can only be answered in the course of the entire discussion. But we shall at the outset dogmatically anticipate the nature of the reply that will be developed in the subsequent lectures. Ideas, theories are originally products, causes of non-intellectual forces. Thinking arises so to speak only in the thin cracks of solid habits, and only with great difficulty penetrates the resistant

\section{[End page 4]}

mass. Or it plays fitfully and like a phosphorescent gleam over the surface of vast ocean of traditions, customs and special adaptations to circumstances. But nonetheless it does have, had had, a really practical influence, and under certain conditions, to be dealt with in the next lecture, may have a greater directive influence on affairs. Effects after they are 
brought into being get intermingled in all living forms with the causes that evolved them and modify the forces that produced them. German philosophy [was] a product of German conditions, not a deliverance of pure reason. But after it had become current [?] and infiltrated into the minds of men, conceptions of system, order, efficiency, confirmed and substantiated causes that might otherwise have passed away in time; it translated over into minds of men what otherwise might have been passing events, it steadied, stabilized, perpetuated transient physical causes. No need perhaps to argue in a country where Confucianism has been a force for two thousands years that even admitting the concrete and practical origin of the system that it organized solidified and focused and rendered persistent factors that without the intellectual formulation might have proved temporary. Not ideas or theories by effective. But human beings who

\section{[End page 5]}

6 different machines, than if they entertained no such ideas or if they entertained different ones. This is true even when ideas are false. A man with an illusion acts differently from one without it. And while perhaps the main effect of philosophic systems has been to consolidate spread and perpetuate the force of conditions that otherwise would have been local and transient, yet they have also an exciting and driving force especially in times of crises. The materialist admits too much when it says that theories, ideals are tools used hypocritically by controlling vested interests to sway masses. For the assertion admits that men are moved by ideals, and that they can be stirred to act in masses and energetically against danger and odds only by appealing to ideals, to general conceptions. "Kultur in danger," on one hand, "liberty in danger" on the other. If great numbers of men had not been made to believe this, the war could not have been carried on. The most that is proved is that general ideas are so efficacious, so powerful in times of crises, that the purely material economic interests of the

\section{[End page 6]}

7 few can be executed only indirectly by acting upon the more idealistic desires and beliefs of the many. Especially is this true under recent conditions of warfare where the old direct motives of personal exploits and glory have lost efficacy - general motives, patriotism, national feeling, justice, humanity, etc. have to be brought into play. No conception is falser than that of men actuated by calculations of self interest. In many respects the world might be better if there were more prudence, more enlightened selfishness, more deliberate weighing of advantages and disadvantages. Action still rests upon instincts and emotions rather than calculation but many instincts can be brought into play collectively only by means of stimuli of an idealistic kind. And systems of thought, philosophies, that are abstract for the few condense into such simple and moving mottoes, war-cries, ideals for the many.

\section{[End page 7]}

The reason for giving much time to the discussion of the practical efficacy of general ideas and theories is that it serves to bring out the alternative forces that move men customs, established authority, prejudice, vested interests, the ambitions of powerful

European Journal of Pragmatism and American Philosophy, VII-2 | 2015 
men leading them to utilize others as tools etc. The best evidence that philosophy has some power is the fear of it expressed by the representatives and guardians of these interests. Emerson stated the idea rather intensely when he said Beware when God lets loose a thinker on the planet. All things then become fluid. Thinking means the introduction of a novel and in so far incalculable factor - a deviation or departure, and an invention. The hidebound conservative is justified in the uneasiness which he shows at attempts to formulate and justify rationally even his own beliefs. The appeal to reason that is implied is unsettling.

\section{[End page 8]}

We must discriminate however between the different ways in which theories have practical influence. In general we may distinguish three types. First those which are aware primarily of the defects in existing institutions and which criticize and condemn them. They conceive of a different ideal state, so different as to be opposed in a wholesale way and capable of realization only in some revolutionary way. They are idealistic, if not romantic, utopian, in tone. They find the true standards and models of life in something apart from and beyond existing affairs. They hold that the mind has been corrupted by contact with things as they actually exist until it fails to perceive the true condition and model. But if the confusion, darkness and error due to this influence be removed, then inner illumination will enable men to see the truth and bring about a radical change. It is thus sudden, abrupt in its conceptions, and appeals to self-reliance, to inspiration from within, combined with contempt for the existing state of things and its corrupting influence. Under different conditions, something of this type is

\section{[End page 9]}

reflected in Plato's Republic, the social aspirations of the early (as distinct from later) Christians, Shelley's poetry, the attitude of Lao-Tze. It expects things now despised to overthrow those now esteemed, the weak things to confound the mighty; ideals to command the actual. It colors thought in times of great social change; French Revolution, Russian, looks forward to a new heaven and hearth.

11 The second type is sober, prudent, conservative. It aims at justifying the spirit of existing institutions. It finds the true patterns and standards within affairs. It looks askance upon change, especially abrupt change, because evil is due to departure from necessary meanings and fixed relationships embedded in things. Reform is restoration, recovery of these true patterns. That is the attitude of such men as Aristotle, Confucius, Hegel. While the first type is critical and pessimistic of things as they are, this one is complacent or optimistic. Essentially if not incidentally things are right and reasonable. Evil is rather in the mind that has departed from them. Instead then of appealing to the mind itself to find within itself intuitively and innately ideals for change, it holds that the mind must be

\section{[End page 10]}

instructed and rectified by careful study of the things forms and relations that are external to it. Its temper is realistic not idealistic. It aims at reform of character and mind to bring them into conformity with the true meanings of established institutions and relationships, not at reform of institutions by appeal to the inner ideals of the illuminated mind. It teaches self-distrust, 
distrust of enthusiasm, impulse, the importance of patient study and instruction from without. It tends to subordinate the individual self, as the radical type tends to exalt it.

Now both of these types of theory in spite of their profound antagonism to each other agree in being wholesale - in taking a general attitude [of] either condemnation or justification toward things as they are. Both of them then lack the kind of practical power or efficacy most needed - power to project and direct the changes that are required. The first expects some sudden and revolutionary change to bring in an ideal condition; the second resists all change. But what humanity needs is ability to shape and direct the changes that are bound to occur. The conservative [type] lacks leverage for guiding change because it consecrates and justifies things as they es-

\section{[End page 11]}

sentially are. The radical and idealistic type lacks leverage with things as they are because it opposes the inner ideal to the outer affair and institution in a wholesale way. The net result is either negative and destructive action or else inaction, passivity, waiting for the ideal to be realized by some miracle of change.

The following lectures will attempt then to state and apply the third type of social and political thought, criticizing those historic philosophies which upon the whole lean to one or other of the first two types mentioned. The next lecture in particular will be devoted to an exposition of the chief traits of the third sort of theory.

[End page 12]

\section{Lecture II [Chapter Science and Social Philosophy, pp. 54-63]}

The entire history of the 19th century in the West is marked by attempts to create [?] sciences as distinct from philosophy of society. Political economy, political science, science of government, of anthropology, languages, religions etc, sociology, [science] of history, even of morals. These efforts express a reaction against the control of human affairs by mere habit, by vested interests, by authority, by accident and belief in miracle. [They] Mark a belief in reign of law, in uniformity of nature, in human and collective affairs as well as in inanimate nature. They were the fruit of the advance of natural science, and the mark of confidence in [the] ability of the human mind to subjugate also the seeming wilderness and irregularity of human activities. When the positivistic matter-of-fact spirit invaded the consideration of society and politics, philosophy was condemned as speculative and pretentious, unverifiable. We cannot go into the fortunes of these attempts at social science. But roughly speaking, it may be said that so far they have fallen short of realizing their claims, and have in a certain sense been more artificial than the philosophies they invoked [?] to replace. They selected certain facts, characteristic of a particular

[End page 1] 
epoch and state of affairs, and making generalizations that described the main features of those particular epochs, laid them down as universal laws, as sweeping and as necessary as the laws of physics or astronomy. The so-called science of political economy for example arrived at generalizations concerning the activities of men in the capitalistic competitive regime characterized by production in bulk for a distant market with exchange governed by financial credit, by money, for money profit. It was a theory of business. Then in order that the generalizations might have the rank of a science, they assumed that these generalizations apply universally to the industrial and economic activities of men. A knowledge of China or of past history is enough to prove that we are not dealing with a science but with certain tendencies predominating at a certain limited portion of time under peculiar historic conditions. The same may be said of political science. It is in fact a description of certain forms of institutions which have been developing in the West during the last few centuries and which especially characterized the Europe of the 19th century, the nationalistic territorial state with a constitutional and representative government based on a certain kind of suffrage.

\section{[End of page 2]}

17 Claim to universality is absurd when the whole range of human affairs is taken into account. Only a deification of local and possibly temporary circumstances. The "sciences" may be called more artificial than the philosophies because the latter were more or less frankly imaginative and speculative, telling what should be, while the sciences claimed to give an account of things as they must be.

II. This does not mean the sciences are useless or negligible. Aside from representing the feeling that (1) human affairs like physical [ones] can be investigated and understood, aside from (2) bringing to light a great amount of valuable facts, they introduce [a] factor which must profoundly modify the social philosophies of the future. (3) The scientific spirit , the scientific method in its larger sense as a way of dealing with facts and plans is their contribution, and it is this contribution which makes possible and necessary a third type of political theorizing, in distinction from the two kinds considered at the last hour, a type which may possess the directive power they lacked. There is (1) the importance attached to actual facts and the need of basing theory upon them. There is (2) the need of abolition of injecting into accounts partisan glorification and

\section{[End page 3]}

condemnation, distinguishing between phenomena and one's wishes about what they should be. (3) The reduction if not elimination of the dogmatic and authoritarian habit of mind; (4) the willingness to take things in detail rather [than] in sweeping generalities, retail rather than wholesale; (5) the willingness to treat alleged principles and laws as only provisional hypotheses; (6) the creation of a demand for experimental verification - all of these things are due to the influence of the spirit of science and they persist when the sweeping claims to scientific laws of universal scope is dropped. THUS THERE ARISES THE POSSIBILITY OF A THIRD TYPE OF SOCIAL PHILOSOPHY DISTINGUISHED IN IMPORTANT REGARDS FROM THE TWO CONSIDERED AT THE LAST TIME (Will condense the above in lecture). ${ }^{1}$ 

thing about the classic systems of philosophy is that they thought with a purpose in view. They were not satisfied with mere description or observation. They tried to educe principle for the directions of life, principles to be used in judging the value of events and in projecting plans and purposes. Nothing less than this can content man in social affairs. For we are not mere outside observers; we are sharers, partners. Our own destiny and fortune is [at] stake in the course of events. We want them to turn out one way rather than

[End page 4]

in another way, and we use our observations of what is in our order to make decisions about [what] may and shall be. In the so-called pure sciences we take the position of merely looking at things to note what is going on. We are outside of them. Our own hopes, fears, desires and observations have nothing to do with the future changes of the moon. The scene so far as we are concerned is a closed and finished one. Our own activities do not enter into its making or remaking. It is only in the "applied" science, like agriculture, medicine, engineering (civil, mechanical, electrical) that we use our knowledge to enter as active partners into what is going on to make it different from what it would be if we do not act and act upon our own knowledge.

In other words the social sciences are not pure; they are like applied sciences. They are concerned with the intelligent reshaping or alteration of existing conditions. It has been said that we know backwards; what has been done - a fact is something done - dead, done with. We act forward; an act is something still doing to change things. Bergson has pointed out that we cannot have the same kind of science of life that we have of the inanimate. We are deal-

\section{[End page 5]}

ing not with [the] finished and self-repeating, but with the unfinished, where the new, the truly novel enters in, and where we are ourselves interested, concerned in what is to happen and deliberately try to make it different in quality, to invent and reconstruct and alter, and where our knowledge of what is and has been is inevitably subordinated to our efforts to give future happenings one shape rather than other - where our knowledge in short is practical like that of the physician who attempts by acting upon what he knows to produce health in place of disease. It is absurd to suppose that we can have a cold-blooded social science that eliminates desire and preference and emotion and bias. But we can clarify and enlighten our desires. Our art of medicine depends upon a bias in favor of life. We want to live, we insist upon it. We use the cold theoretical knowledge of chemistry, of anatomy and physiology to direct our want, our desire more effectively, to make our bias more adjusted to conditions, less blind and at the mercy of accident. Hence the primary features of our third type.

IV. It is pragmatic, instrumental. That is, it aims to be an art, an applied science, a form of social engineering. Politics is an art, but should not be a blind or routine or magical art, not directed by intrigue or vested interest etc.

[End page 6] 
on the possibility of introducing more conscious regulation into the course of events in behalf of the general or public interests. It believes that the art of politics is now too much an art of special manipulation in behalf of particular and concealed interests or ends. It may become an art like the art of engineering in quality, if not in extent and quality. The building of railways and bridges, of canals and electric dynamos recognizes the supremacy of human aims and desires. It uses factual knowledge in behalf of collective human ends and purposes. But the use depends upon positive sciences and hence is not blind, random, accidental, or merely traditional. It can conceive and execute new things in an orderly way that turns the course of natural phenomena in definite channels. In like fashion our social and political notions and theories and systems must be used for social constructions, for social engineering and must be subjected to the tests of such use.

V. Hence social philosophy must be specific, not universal. Nobody builds a railway in general. We build a particular railway with reference to specific localities, their geographical features, rivers, mountains, valleys, the position of

\section{[End page 7]}

towns, the distribution of the population, the raw materials, economic resources occupations and products. In other words, the project is based upon a study of a special concrete situation, the needs that have to be met, the resources at hand and potential, the obstacles to be overcome, the definite aims in view, consequences to accrue, political, industrial, financial etc. The problem is one of ends and means in a particular situation. In contrast with this classic social philosophies have been wholesale and absolute. They have laid claim to universal validity, good for all time and places and circumstances. General radicalism or general conservatism, instead of changing and conserving special factors according to the needs of the particular situation in which men actually found themselves. Everybody knows the part played in historic philosophies by individualistic and universalistic theories respectively by those which have emphasized the initiative and freedom of the individual and those which have emphasized the state, law and order in general and the subordination of the individual to them. What has not been a part of these philosophies is of necessity - since there is a place for both elements in life, his-

\section{[End page 8]}

toric conditions may lead to the need of emphasis upon the factor at one time and another factor in another - that neither philosophy is true universally and abstractly speaking but both are applicable under specific conditions. Because men do not build tunnels on a plain is no reason for formulating a theory that tunnels are always objectionable and thereby retarding building of railways in mountainous districts. In Europe in the seventeenth century there was a general break-up of institutions, a scene of wars religious and civil. It was natural that in this threatening chaos and dissolution of civilization men should have prized order, and looked to authority that had the power of enforcing it. The conditions favored unification and centralization. But the non-scientific absolutistic habit of mind took the need out of its context and made a universal and necessary principle out of it. It has favored the formation of a new evil, absolute and tyrannic government in process of correcting the existing ill, and contributed to latter times the tradition of an authoritative state - such as influenced Germany in the nineteenth and twentieth 
century. On the other hand, the later part of the eighteenth century was a time in which the industrial changes due to [the] use of steam in manufacturing had made obso-

$$
\text { [End page 9] }
$$

lete and harmful many laws, institutions and practices that had grown up in prior conditions in which they had worked more or less well. But under the new conditions they worked inequitably and in a hampering way. They needed to be swept away to give freer play to the new enterprises made possible by the use of steam in production and distribution. To be successful and to be able to make their contribution to the public benefit, individuals needed to be emancipated so their own initiative should have more scope. But unfortunately this relative and specific need was frozen into a universal principle. All social regulation of industry and business were proclaimed to be evil. No collective direction of economics by the organized deliberation and decision of society was possible and desirable. The functions of the state must always be limited to protecting individuals in the exercise of their freedom as long so did not encroach on a similar freedom of others. Laissez-faire and the police theory of law and government. In short a movement valid within certain limits, those of the historic situation in which it arose and with reference to which it was remedial, was erected into an absolute and universal truth. Later on the

\section{[End page 10]}

evils of this conception became apparent, and there was a corresponding reaction in the direction of state socialism, of general state ownership and regulation of all business undertakings, free individual activity and competition were declared not simply to have led to evils under the particular conditions in which they were conducted, but to [be] bad inherently. This oscillation from one extreme of theory to another is illustrative of what happens wherever the wholesale and absolute type of theory prevails. What is needed is to see that every philosophy since it has a practical aim is relative to the specific situation which requires rectification. We must think within limits set by special ills and special resources at hand for correcting them. Avoid large, general isms, and consider specific questions, using the isms simply for what light they may throw on the special need at hand. It is especially the tragedy of warm enthusiastic social idealisms that in the long run they play into the hands of reactionaries by thinking and talking in impossibly wholesale terms, forgetting that development is a matter of a very large number of specific changes that have to be accomplished in detail one by one, and that to try to do everything in a general way is likely to result in failure to do anything

\section{[End page 11]}

in particular except by chance.

VI. Hence the third type of philosophy substitutes discrimination of particular consequences of good and bad, better and worse, for general criticism and justification. It tries to find out how this and that arrangement, custom and institution works in detail to promote happiness or misery. It aims at amelioration, at improvement of this and that bad feature rather than at either universal condemnation and destruction or consecration and conservatism. Progress is its watchword, while it also recognized that progress must be in definite points where reorganization is needed, and not all over at once. It recognizes that there must be 
found positively good things, to use as tools and resources, as active agencies in correcting the things that require improvement. It avoids the illusion (1) that things are essentially unchangeable because human nature is always the same, and (2) the idea that any single sweeping change of law or intuitions can be successfully accomplished all at once. Especially it looks to education, to enlightenment and equipment of specific human beings , to introduce improvements and to make them genuine and enduring, rather than to any magic wand of enactment or legislation or outer administration.

\section{[End page 12]}

Reverting to question of the practical efficacy of theory, it be said that traditional types are of actual social effect accidentally rather than purposefully. They reinforce customs that exist independently of them by rationalizing and justifying them. Or they express strong emotional likes and dislikes and inspire men to attack. But they are not purposefully useful. They are useful the way a tree happens to be for plowing tho it was not intended for that use. But ideas that are framed from study of special conditions will be valuable and valid just in the degree in which they help solve problems. Moreover [they] are subjected to test by verification. [They are] Taken out of the region of assertion and brute force and mere argument. Social philosophy should be a bridge from the existent unsatisfactory situation to a better future state of things based upon accurate knowledge of evils to be corrected and definite projects of change at this point and that.

[End page 13]

\section{Lecture III [Chapter Social Conflict, pp. 64-71]} is a number of people associated together for some purposes, some common activity that holds them.

\section{[End page 1]}

Human nature has a variety of interests to be served, a number of types of impulses that have to be expressed, or instincts that form needs to be satisfied, and about each one of the more fundamental of these some form of association, of living together or of acting together continuously or repeatedly and regularly (as distinct from mere chance and 
transient contacts). Above [?] the sexual need and the function of reproduction there grows up the cohabitation of man and woman, and then the adhesion of children - the family group or form of associated life. The need of support, of sustenance and the need of regular activity, of impressing the energy of man upon nature, develop association for industry and business. Again men associate for worship, for religious ends and churches, monastic orders come into existence. Men's interest in investigation and discovery make them join together for educational ends, schools, learned societies, etc. The need of regulating men's conducts, their behavior to one another, protecting public order etc., and the desire for power and authority give rise to gov-

[End page 2]

ernmental association, political society. Aside from the hundreds of special associations for amusement, companionship, common feasts, which are more [or] less temporary clubs, we have these fairly universal modes of union and association.

We can frame in imagination a picture in which there is an equal proportionate development of all these forms of associated life, where they interact freely with one another, and where the results of each one contribute to the richness and significance of every other, where family relations assist equally the cooperation of men in science, art, religion and public life, where association for production and sale of goods enriches not merely materially but morally and intellectually all forms and modes of human intercourse - where in short there is mutual stimulation and support and free passage of significant results from one to another. Such an ideal picture is of use only because it helps us paint by contrast the state of things which has actually brought about social divisions and conflict. European history for example was marked for

\section{[End page 3]}

centuries by such a predominance of association for religious purposes, by the church, that other modes of life were more or less suppressed, choked, dwarfed, or deflected into one-sided channels. Family life [was] affected because chastity was supposed to involve abstinence from marriage, the celibate life [was supposed to be] superior; industry [was affected] because wealth and material production was a distraction from the spiritual life; science [was affected] because the results of free inquiry might be dangerous to theological doctrines of the church; art [was affected because it] might instill a love for the things of the eye and the flesh at the expense of divine things. So these were allowed and cultivated only as they took a form subordinate to the dominant religious interest; they had to be made to contribute in a one sided way to the supremacy of the church architecture, music, painting, philosophy etc. Then again for some centuries history was marked by a struggle between the church and the state, between human combination in the interest of religion, and in the interest of organized secular public life - religious wars etc. [The] Struggle [has] not ended

\section{[End page 4]}

yet. Contemporary politics [in] France, Italy, and even the educational problems of Great Britain cannot be understood without reference to it. During the seventeenth and eighteenth centuries the history of the progress of natural science is largely a history of 
conflict of the interest in observation and inquiry with the better established authority of the church.

These conflicts of institutions are so common that we take them for granted as almost the very stuff of history itself. They are here referred to because they prove so conclusively that men's various interests do not march four abreast, evenly and uniformly. Some interest with the form of association in which it is embodied gets a particularly intense and widespread start; it then lords it over other interests and associations and makes them tributary so far as may be to itself. It insists upon dominating activity, monopolizing attention and interest. Free give and take, mutual enrichment, reciprocal stimulation is prevented. Then the interest in

\section{[End page 5]}

question becomes isolated; it ceases to be fed by natural sources; it becomes rigid, petrified, fossilized, and unless its pretensions are broken down and interaction and balance restored, it decays, there is general relapse and stagnation, corruption. Some force has to come in from outside to stir things up and bring about a vital interplay of social activities. A mode of social life that is monopolistic of human energy and attention, comparatively speaking, necessarily becomes itself one sided; it lacks the contacts which will give it fullness and an all-around character. It becomes at once harsh and relatively empty, barren.

We may take another example from present conditions. The last two or three centuries has seen a great growth in the importance of the political organization known as the state. After becoming emancipated in Europe from the control of the church, it has tended to become an all-engrossing thing, as is evident in the doctrine of the Sovereignty of the State. Two stages are obvious. At first, the state was identified with the government, and the control of the governing group was so great

\section{[End page 6]}

that it was looked upon as despotic and tyrannical, and constitutions and representative government and general suffrage were brought into existence largely to check arbitrary exactions on life and property. Civil freedom required checks on governmental action. 1688 in England, 1789 in France. In the nineteenth century, state became identified with the nation as an organized whole dealing as an entity with other nations. The late war is a proof of the ascendency of the state interest; the sacrifices and subordinations of life, property, freedom of industry, thought, science, publication it is capable of exacting. The government as the universal carrier. Now there is a reaction against the very idea of the state. Such as the doctrine of anarchy or purely voluntary group associations. This doctrine flourishes only where and when the state has become exaggerate and rigid, and other forms of association thrown out of balance.

In general it must be noted that certain areas and times have tended to concentrate upon certain forms. Greece upon civic life, the organized community, city-state; Medieval, the church as noted;

[End page 7] 
the East, the family principle; the contemporary West, especially America industrial and economic groups cutting across the other forms of life, and tending to subordinate them to its own unchecked aggrandizement. In dealing then on the basis of theory with any particular social condition we need first to ask what pattern of human association tends to be central and regulative; what are the one-sidednesses and arrests, fixation [and] rigidities thereby produced; where are the suppressions from which society is suffering in consequence; what are the points of conflict, strife, antagonism of interest.

The point of view may perhaps [be] illustrated by a sketchy and superficial account of the tendencies and problems created by when the family or blood-kin basis gets exaggerated.

There are good reasons why the family principle should be expressed first historically. The perpetuation of society depends upon the union of man and woman and the care, physical and intellectual, of the offspring. The family is not merely the family. It is also the household,

\section{[End page 8]}

which is the economic and industrial form of association. Aristotle's conception of economics, domestic, property, reproduction of life, property, slaves serfs, political economy that of state, public finance and property etc. Arts perpetuated [?] in family apprenticeship, adoption into the family guild. But the authority of parents, especially of male, exercised in the family and [in the] household group made family absorb functions of political association. Patriarchal rule. Even after families were consolidated into a civic community, the authority of the ruler was often that of the head patriarch, the dominant family among a group of families. Primitive family [was] also the religious and educational unit. The father the priest; the household alter, divinities; ancestral worship, filial piety. The dominant pattern, others subordinated even when they split off. Contribution of family idea to ethics. Intimacy, love, care protection, ties of blood and kin, God the father, all men brothers. But [there were] certain evils. Summed up in subordination of women to men, women [being] passive means of reproduction, and of inferiors to superiors fixed naturally, physically and unalterably. Aristotle - on position of women; and some persons naturally slaves, tools.

\section{[End page 9]}

Certain classes in community not really parts, sharers in community life but external means, must live, supply conditions to higher, leisure class that devotes itself to higher things. All the more significant because Aristotle was not moved primarily by family idea but civic; family only survived and projected itself. In politics generally, the state began as the Es-tate, the dominion of the ruler. The dominion, that over which one exercised rule, lordship, authority, was the same as property. Women a property. The maxim of English law; husband and wife are one and for legal purposes the husband is that one. The religious factor came in - early political societies theocratic - divine right of kings. The king - the direct representative of God - perpetuated long after the priestly function was obscured. The mystic value, mysterious and emotional, awe, reverence. One of the chief obstacles to straight [?], sensible treatment of government. 
it is] obvious that all these things involve a one-sidedness and distortion of human nature - suppression of growth in some direction, exaggeration in others. Lordship, mastery, authority stimulated out of all properties

\section{[End page 10]}

in a few. The qualities that could be developed only by direct share in associations for advance of intellectual life, art, industry, religion, inhibited. Even as these forms of association grow up, they are not free to grow; they have to accommodate themselves to habits carried over from a prior dominate association.

That the unequal and unbalanced development of forms of life is the source of social difficulties in general and that the problem of theory is to detect these causes in detail and provide plans for remedial action thus appears. We have to add however one more source of conflict from this source. We have not mentioned the local, or territorial source of combination in life. The neighborhood, acquaintance, familiarity, as bond of union. Our village, district, province, nation, as distinct from outsiders, instinctive attitude toward the strange, alien foreign in appearance and custom, habits, clothes, one of suspicion, fear dislike. Our church, club, clique, circle, party, college, class, those who have the same habits, who are familiar with one another and under-

\section{[End page 11]}

stand one another. Exclusiveness, prejudice, jealously, isolation, hostility - from national wars to local jealousies. Who is my neighbor? Who was neighbor to the man who fell among thieves? The idea the need and capacity to help, to be of use are bonds of union irrespective of local contiguity and the familiarity that makes [them] possible is one slow to appear and hard to realize. This principle of association cuts across all the others, runs through them all. It adds new sources of social discord and ill, and intensifies all the old ones.

40 (At the present time, the need for social philosophy [is] urgent because the increased mobility of life has affected both the great principles of association. Old forms of association are thrown out of gear, family, church political [party], school, because of the rapid development of industrial changes. These also have brought local groups into closer contact with each other increased sources of friction in increasing those for combined action and cooperation. Made common understanding more important and organization to perpetuate it. Critical state of world\}.

[End page 12]

\section{Lecture IV [Chapter Social Reform, pp. 72-81]}

The point of view presented at the last hour was that the practical difficulties which lie back of theoretical social problems are due to the exaggerated development of some one interest in a given type of society, the family, the religious, the economic, the political, that of personal acquaintance or whatever. This exaggerated development of some interest brings groups or classes of persons into conflict with one another; it leads to 
friction, contention, strife and division, and to confusion, disorder and uncertainty. For at some point the suppressed side of human interest, the instincts that have not got expression and satisfaction come to consciousness, and they claim the right to operate. And they are not abstract but are embodied in definite groups of persons. There is no struggle between science and religion, between church and state, but there is one between those concrete human beings who exercise, say, the controlling power through the church and other men and women whose instincts to investigate and discover or to promote secular welfare, or achieve political power, are repressed and thwarted.

This however is not the usual way of stating the origin, the source and nature of the social problems that form social theory. It is usually said that the conflict of society and the individual is such as to lead to the need of harmonizing or adjusting the respective claims of one to the other, and that social philosophy is the theory as to which [is] to [be] supreme or how the claims of one are to be reconciled with the those of the other individual liberty with social control, freedom and authority rights and law etc. Today we take up two questions. (1) How does it happen that social philosophy has become so preoccupied with a wrong conception? And (2) what practical difference is there between the two ways of stating and attacking social questions? Is the difference anything more than an academic one, a speculative difference?

One set of persons represents and embodies

\section{[End page 1]}

the dominant, law-interpreting group and other persons the subdued, depressed, comparatively dumb group. The former have the authority, the prestige of custom, to back them. Just because they represent what is established, the customary and instituted order, they appear to embody the claims, authority and majesty of society. The persons who represent the relatively suppressed group will appear to behave socially, to be actuated by social motives just as long as they accept the existing state of things and conform to its traditions and prescriptions. When they revolt, and desire to change things in order that some other social interest may have fuller expression, they do not appear to be acting in behalf of any social purpose or good at all. They are placed in the position of making claims on their own individualistic account because they do not have the sanction of any social aim which has become acknowledged authoritatively. Thus it comes about that egoism, selfishness, which has become established by custom, which has attained recognition and prestige, puts on the garb of social sanc-

\section{[End page 1 bis]}

tion and moral standards, of law and order, while activities which in reality express a wider and more just social arrangement are held to be lawless, manifesting the selfish desires of a number of individuals to disturb society in behalf of their own egoistic indulgences and ambitions. This struggle for the rectification of social inequalities which affect large groups and interests and functions in their relation to one another is the primary reason for the belief that the primary problem is the conflict of society with individualism and that the chief problem of social theory is to determine which has the superior claim and authority. 

religious embodied in the ecclesiastic institution, the latter occupied the place of social advantage. The social benefits and organizations represented by freedom of thought and belief, of worship and conscience, were in the future. They were, so to speak, matters of

$$
\text { [End page 2] }
$$

faith.

The church was a social organization that exercised positive social functions of instruction and control; its social quality was a matter of sight. Just because the scientific interest had not been allowed to function freely its power as a source of organization and direction, its place as a basis of human association and companionship, could not be demonstrated. Hence the representatives most naturally asserted that they represented the claims of individuality, irrespective of or even in opposition to social organizations, the claims of individuality [against] a force which shackled and tyrannized. On the other hands, the representatives of the church naturally conceived of themselves as upholders of law and order as conservators of all the social values that alone made life worth living and that restrained human nature from indulging in unbridled excess. They claimed that the innovators, those who wanted freedom of belief, worship and teaching, were actuated by anti-social purposes, that their claims to spiritual and moral freedom were merely cloaks for

\section{[End page 3]}

sinister self-interest which wanted to subvert society so that there would be no check on vicious egotism and self-seeking. In short one form of self-seeking, of selfish aggrandizement had been [illeg.] so institutionalized, so wrapped up with all forms of life, and so controlling, that it did not seem to express selfish ambition and aggrandizement, sheer love of power at all. It was an expression essentially (even though marred by inevitable human defects) of the principle of social authority and illumination.

Perhaps a still better example is found in the state of things that happens when society is primarily organized on the family pattern, when the family association, clan or household, is the ruling one. In such a situation, the egotism of adults and of men, of the male adults, is stimulated, but at the same time it gets a strong social sanction - it acquires the appearance of being actuated by high moral motives of preservation of social peace and order, the conservation and perpetuation of the traditions and ideals by which society lives and is made possible. Just in the degree in which the special and one-side interests of the male adult become institutional-

\section{[End page 4]}

ized, and standardized, vested interests, and they become influential, that is to say actually bound up with all forms of social intercourse and relationships, affecting all ceremonies and the trend of thought and action, those interests take on social justification, glory, prestige. An innate egotism is clothed and armed with socially important purposes and supports. Any movement then for greater freedom on the part of the young, freedom to select vocation, to choose their own mates, to make their own political affiliations, to 
determine their own moral and religious beliefs is presented not merely as a conflict of personal wills, of one set of individuals over against another, but as an attack of licentious individualism upon the foundations of society; as leading to lawless individualism, overthrowing all coherent social authority, because undermining organization. On the other hand, the young, while they may feel a strong faith that the accomplishing of their desire for greater freedom would improve society and put human relationships on a secured basis, can not prove it by pointing to an established order where this state is realized.

\section{[End page 5]}

feminism - the movement for the rights of women, the emancipation of woman. Rights to an education, to a place in industry or economic independence, to engage in professions previously engrossed by men, to take part in making laws and administering them. Now it is clear that that has not been generally thought of as a struggle between social groups, or between sets of individuals. It has present-

$$
\text { [End page 6] }
$$

ed itself as [a] claim for greater liberty on the part of some individuals, as at its best a protest against social abuses, tyrannies, oppressions. While those who did not like it, whose comfort privileges, enjoyments and power were disturbed or threatened, regarded it as an antisocial willful attack upon the very foundation of social relationships on the part of a few aggressive, more or less ill-natured and disappointed women. As a matter of fact it is an incident of general social changes, of new action of social forces bringing about a reconstruction of social groups and of their adjustment to one another - not to be specific a destruction of the family, but among other things an insuring that the humane and sympathetic interests and aims of the family which have been the especial charge of women shall not be confined within the walls of the home, but shall have a chance to [be] carried into schools, shops, factories, professions, politics etc., and that the more impersonal, abstract and possessive interest of the male shall

\section{[End page 7]}

no longer so dominate action as to set up barriers against the free give and take of social groups and the interests which they represent.

It is interesting to note that it is in the earlier stages of a movement when its object is least evident, when it takes the most the form of a protest, that its so-called individualistic 
character is most evident. We may indeed distinguish three stages. In the first there is such an equilibrium that the suppressed group or class is not aware of its suppression, or takes it as part of the established and necessary order of things. There are not opportunities that suggest an idea of a different state of things, and hence no idea of an effort to bring about change. When slavery is most complete, when government is most successfully despotic there is no thought of slavery or despotism as evils to be protested against. Only when conditions are such as to stimulate a consciousness of powers which are not expressed and satisfied is there definite revolt and effort at change. When industrial changes took away

[End page 8]

from women household activities that had belonged to them previously, there was not only relative loss of activity, but also a leisure for other things. Better education was given. This created a sense of powers that had no outlet and created restlessness and uneasiness which didn't exist as long as women had [been] more completely absorbed in the household life.

The second stage is than that of restlessness, discontent, because social conditions have changed enough to arouse a sense of powers which do not function, which have no definite social channel provided for their utilization. This is the period of marked "individualism" of revolt against authority and established institutions, a feeling that they are [either] merely conventional, or else positively oppressive and to be destroyed in the interests of individual freedom, which is negatively viewed [as] absence of restraint doing as one pleases etc. (3) But as social organization proceeds and the capacities of the submerged group are not merely stimulated and brought to consciousness in an emotional way, but get some definite channel of exercise, the demand ceases to be for individualistic expres-

[End page 9]

sion, and becomes a demand for a chance to perform a badly needed social function. The claim shifts from a right to a neglected social duty.

There are similar stages in the growth of the scientific interest. (1) At first it is merely submerged; there is conformity, acquiescence in whatever ideas are current. The authority of custom is so general that it is not felt to be an external authority; it is just part of the regular and unquestioned order. Whatever independence or originality exists finds vent in framing fantastic tales, or myths and legends which do not conflict with the recognized system of beliefs. Then as some event, generally contact with people having different ideas and beliefs or with unusual natural phenomena through travel, arouses doubt and questioning. (2) Doubts and questions are however usually resented by the existing social, ecclesiastic and political regime as involving an attack upon its authority, as anti-social, subversive. Persecutions, strong or mild [take]

\section{[End page 10]}

place. Hence the new inquiries, which represent the rise out of its submergence, are likely to identify the existing social order with society itself and to claim the right of free 
inquiry and belief not as right to exercise a power socially needed, but as a purely personal, private right, inherent in them as individuals, irrespective of all social bearings

\section{[End page 11]}

The natural right to inquire and chose belief is said to be supreme even if it involves social subversion. (3) In the third stage, the scientific movement has got enough organization, it has grouped about itself a sufficient number of persons, so that it has a social standing and repute; it has enough headway so that its social bearings are apparent, and the claim of the right to exercise the scientific interest is made in behalf of social need and welfare not in behalf of purely individualistic non-social factors.

The same three stages may be detected in the history of the labor movement. First slavery and serfdom acquiesced in on both side as matter of course. Second, a social change that arouses a consciousness of wants and desires and a realization of suppression of activities - a movement of revolt, of emancipation, of claims for personal rights and enjoyments. Natural, inalienable rights to life, liberty and the pursuit of happiness residing in the individual irrespective of social consideration. Thirdly it is seen that these are only mask for a social need and concern: the demand that laborers

\section{[End page 11a]}

have the education, the resources, the cultivation and power so that society can have its work done most effectively and happily.

II. What practical difference does it make whether we adopt this point of view or the traditional one of conflict and adjustment of social and individual? The answer is that the latter leads to the formation of opposed groups based on emotion, prejudice and vested rights and wrongs, and stimulates resort to the method of dispute, recrimination and even physical force. Men takes sides for the social in general, for authority and control in general or for liberty and individualism in general. There is assertion and counter-assertion, bitter quarreling, but no way of arriving at a common conclusion by the use of intelligence in analyzing specific conditions, studying definite problems of cause and effects. Blind adherence to conservatism and to change, under conditions which makes the first despotic reactionary and the second destructive. If the point of view here urged were generally ado-

\section{[End page 11b]}

pted, it would be recognized that institutions, conventions, modes of social control that direct the thoughts and acts of the members of society are bound to grow up; they are inevitable; it is impossible to get rid of them - to destroy one form is only to set up another - as [it] may be seen in the rule of the Bolskeviki after destroying that of the Czars. It is not only inevitable, but also in some form indispensable, useful. The real point is to discriminate among them, for customs, conventions, institutions are better and worse, and the point is to keep the good and improve or do away with the worse. This means an appeal to intelligence, not to bias and prejudice and vested interests, to inquiry to trace causes and consequences, to see what produced this or that institution or arrangement, the historic method, and also to trace consequences, to see how the arrangement works, what effects it produces - and the same for any 
proposed measure of reform, improvement. The practical difference is thus the substitution of the scientific method for the method of opinion,

\section{[End page 12]}

dogmatic assertion, bitter recriminations and disparaging name calling, epithets of abuse. Method of analysis, of taking things in details and discriminating, instead of wholesale isms.

It thus smooths a path for orderly and continuous progress. The innovator has a case to prove. He is the propounder of a hypothesis that the welfare of society would be promoted by the adoption of a certain change, that if this harms a special class for a time, this loss to the class is in the interests of the community of the whole, and is the measure of justice to some other class now suffering from inadequate social recognition. He does not present himself as a mere rebel, hostile to the authority as such, willing to tear down recklessly in a blind hope something better may appear. His claim that certain defects exist, and that they may be remedied by the adoption of certain proposed measures of change are propositions to be examined in the light of facts - first facts of history, existing facts and conditions, second new facts, facts to be brought in.

[End page 13]

\section{Lecture VI [Chapter Communication and Associated Living, pp. 90-98]}

The supreme test of any social arrangement, custom, institution, law etc. is its relationship to promoting living together, association, intercourse, communication exchange of feelings and ideas that makes experiences common (common, communication, community). Does it further full, free all-around passage, transmission of social values, material and ideal? Or does it like the caste system, like classes stratification, build up walls, produce exclusiveness, aloofness, non-intercourse? Does it like the autocratic system in government and industry, like the ancestral patriarchal family system, make the channels of communication one-sided, going from superior to inferior, but checking and clogging any reflex action? Does it keep the social arrangement flexible, capable of modification through interaction with other arrangements, or does it harden and ossify into rigidity? A development of the meaning of such questions, as social tests, criteria, is the subject of today.

57 1. True social or community life means inter-action, reciprocal influence, mutual response to the needs and claims of the other parts of partners in the combination. The import of this idea is best seen in its negation.

[End page 1]

\section{Lecture X [Chapter The State, pp. 125-132]}

We now come to a discussion of the distinctively political aspect of social life. It may be marked off by the nature of the problems with which it deals: These are such questions as 
I) the nature and scope of the State, or the problem of political authority; II) the nature and constitution of Government, or the agencies of exercise of authority, the value of various forms of Government, as monarchy, empire, aristocracy, democracy, pure versus representative democracy, the legitimate powers of government, legislative, executive and judicial and the relation among them, etc.; III) the nature and [the] scope of Law, its relation to Government on one hand [and] to the citizen on the other; IV) The system of legal Rights and Duties or obligations in which the system of law becomes concrete and operative. If we attempt to define the conception of the political instead of enumerating the various problems included in the discussion, we may get help by noting two things. First the conception of Law runs through all the problems mentioned. Secondly, the conception that law has an authority which is not simply moralistic - that is which does not depend merely upon its recognition by the individual conscience but which is enforced even against personal wish by some general agency. Whenever we begin to consider what any particular individual may lawfully do, and what he can do only unlawfully, and what agencies and means prescribe what is lawful and what not, and protect him within his sphere of lawful activities, and limit him, restrain and penalize him in his unlawful activities we are within the sphere of political discussion.

We begin the discussion with a consideration of the meaning of the State as a supreme political authority. We must however note that law and authority are not coextensive with the State as we now know the State, and that the present identification of the problem of the nature of the state with the nature of political authority, the power to make law and enforce laws of conduct is a product of historical development which has not everywhere gone on to the same extent - that for example

\section{[End page 1]}

many of the present problems of China are closely connected with the fact that she is face to face with peoples and countries who have carried the formation and consolidation of [the] State as the centre of social regulation further than China has done. As was noted earlier, the family and clan organization, based on blood tie real or imputed, was doubtless the first organization to exercise control, to determine what its members could and could not do, and to reward and punish them. It contributed the paternalistic or even patriarchal conception to the State when the latter was formed, and in connection with certain religious and moral creeds became the backbone of the absolutistic state, the State which centres mystically in a single family or individual, of a semi-divine or superman character - an Emperor, Ceasar, Mikado. Even the most extreme form of political anarchism - that which desires the abolition of the State - must still recognize the existence of some social group, which as a group, exercises some control and discipline over its members - unions, societies, corporations, partnerships, schools collectively etc. It throws light upon the problems of politics to note that every such organization has rules and regulations, either written or unwritten. While the anarchist may put the emphasis upon the right of any individual to enter or leave any such organization at his own sweet will, yet he must admit that children for example are not in any position to exercise such choice, and that entering any continuing organization entails permanent obligations - that is, puts one under some authority. Thus I knew an anarchist society in the US where every member pledged himself never to vote or take office, to have as little to do with government and officials as possible. The pledge to the organization was of the nature of acceptance of political authority. In practice it will be found that anarchism, or 
the denial of the value and validity of all political ideas and activities, centres in two things: distrust of the State in the forms in which it now exists as a beneficial

$$
\text { [End page 2] }
$$

political agency - not so much a denial of politics as of a certain organ as the best instrument of social regulation, and secondly, in the belief that all exercise of physical force for coercion or repression is unjustifiable. The former point while important is clearly secondary. Now this use of force is usually taken to mark off the region of the legal and political from purely Moral. Hence this problem is central. What if any is the justification for the use of force in connection with observance of law, of rules of notion, and with penalization for departure from the rules which are inherent in every continuing social organization? Shall individuals be left to be the sole judges? Shall the sole penalty be social disapproval expressed in purely moral forms and without regular means of expression - that is, an agreement on the part of all members of the community to refuse to speak to anyone who did a certain thing, would certainly imply political organization and might have physical consequences, sickness and death. Is it wrong to use force or the threat of force to get things done which an individual does not wish to do or to use it to restrict his liberty of action - taking property away from him, putting him in prison or to death? physical. The issue is not between physical force on one side and moral force on the other. It is between an intelligent and constructive use of physical force and a negative, wasteful destructive one. Physical force must be used in any case. The problem is to regulate its use to get the best results; the moral question has to do with its use as measured or judged by consequences. Most physical force used even by a despotic state operates through mental intermediaries - through threats of punishment. It appeals to a motive, and thence a moral factor is introduced. The trouble is that the motive is so largely a negative one, fear, timidity, desire to keep out of trouble,

\section{[End page 3]}

motives that depress and thwart human energy instead of evoking it for use, in those upon when the threat of punitive force is exercised, while in those who exercise it, it stimulates only the most rudimentary mental energies. Possession of force is such an easy resource that it does not call out foresight, ingenuity or consideration of complex factors. In evoking only the cruder human powers, it also encourages an irregular uncoordinated use of them - what we call arbitrary action. Even where the use of force upon the part of governing officials is itself regulated by law, it must be admitted that much force is employed stupidly - as for example in the ordinary jails and prisons. Force is us used wisely when it is used to arouse attention, to make men think, to reconsider their course of action, to form plans better adapted to maintain order. It is used unwisely when it produces only emotional reactions, fear, resentment, hatred, sullenness, or when it dulls and depresses power of observation and reflection, circumscribes thought.

On the other hand, moral force without some physical expression is an impossibility. Every act requires physical energy for execution and it changes the environment in some 
way. The use of judgment, persuasion, reasoning, appeal to conscience, statement of the case are distinctively moral, but they can be manifested only through physical agencies. Sarcasm may be as painful as a lash of a whip, reproof may be harder to bear than a slap. Moreover the use of speech may not be adequate evidence of genuine belief or conviction. What a person is willing to do is a proof whether there is anything more than speech. Talk is cheap. Is the person willing to back up his talk by other actions? Readiness to act upon believe when involving risk is the universal evidence that an idea is real. Ideas and ideals that persons do not care to enforce, to use energy to carry out, are unreal.

If moral force cannot be separated from physical, what then is

\section{[End page 4]}

meant by it? Two elements in moral force; [it] assumes community of interest not hostility. [It] Assumes that both parties have a like interest in reaching an understanding and settlement, and that the other party is willing to cooperate in reaching a conclusion. Much use of force even in behalf of justice and right assumes hostility, antagonism, unwillingness on the part of the other side to come to a reasonable and right conclusion. Hence friction and recriminations are excited. The other person assumes that he can make his claim good only by resort to violence. The excitement of resentment and ill-will produces more new wrongs than were settled. Use of persuasion, discussion, assumes reasonableness and at least moderate friendliness on the part of another party. Kindly treatment is sometimes disarming. Hence even when this method of persuasion by argument cannot be used further because of the unwillingness of the other party to engage, force should be used in such a way as to promote attention and thoughtfulness rather than [as] an end in itself. The question is the kind and manner of using force that will best develop the reasonable attitude. Passive or active resistance, positive punishment or isolation, withdrawal of intercourse?

We may distinguish three grades of force. One power, energy in carrying out ends, which is not only an evidence of good faith and sincerity of belief but also the only way this moral ideas can be anything more than inner idle sentiments. Second is such use of energy as disturbs others inflicts pain or suffering or loss upon others. Now the fact that this is exercised by the state instead of by an individual doesn't of itself justify it. The question is whether it is used in such a way that the loss brings the other party to a more reasonable frame of mind, and makes possible intercourse on terms beneficial to both. Then in the third place, there is violence - force which is destructive, harmful with no educative or restorative affect at all - or one quite subordinate to the destructiveness wrought. It must be

\section{[End page 5]}

admitted that much action by states, as well as by private individuals, and in peace as well as in war, violence judged by this criterion and hence to be morally condemned. But provision of schools is almost wholly a constructive work. Schools require money. If a group of persons refuse to contribute, force may be used to bring them to a better mind (to pay taxes) as well as to carry on the constructive work. Cases of legitimate coercion, compulsion, coercion, fall in this class. 
65 state as an organization is completed. It was said that any social ideal must be based upon the facts, the necessities of human nature and the world. Now the sense of injustice, resentment and redress are very strong in human nature. If there is no public agency of justice private persons will take correction and reprisals in their own hands. In the end there will be more irregular wasteful destructive force, more invasion of the freedom of others, than if there were a public reservoir of force. State action is a draft, a diversion, of private action which is economically expedient. The case is seen in war between nations. What is needed is some superior judge and administrator. Without it, every individual nation arms and betakes itself to force when it thinks or fancies it is wronged. So before the institution of public agencies armed with force, there was more or less a feud, a private war, going on all the time. Moreover without any bad intention persons run into each other and do harm in the course of each carrying out his own plans. Some kind of impartial arbiter with power to enforce decision is needed.

These arguments do not establish the fact that the State should be the umpire and executor. They only point to the need of some outside party, beyond the individuals immediately concerned. When, however, social relations become complicated, and a wider and wider range

\section{[End page 6]}

of interests are affected, when the consequences of acts spread beyond the individual to third parties, the agency called into operation must become increasingly permanent and comprehensive in its action. The obvious objection for example to the anarchistic theory of perfectly free relations in marriage, with no public supervision or control at all, is that the marriage relation does not terminate with the two persons directly concerned. The natural consequence of marriage is children, and their interests must be conserved. If the intelligence and affection of parents doesn't suffice, then there must be an outside power, somebody authorized to act, with coercion and control if necessary. Now the different parts of modern society grow more and more interlaced. It is more and more impossible to say that the effect of any act is limited to the parties directly engaged [?] in it. The effect upon the interest and happiness and positive freedom of others is such that there must be an agency at least as extensive and enduring as the interests concerned. Hence the development of the modern state. It is fair to say that if the anarchistic experiment were tried with good faith and intelligence under all [the] complex conditions of civilization and over any large territory, it would soon develop an agency for regulation and for settlement of disputes and conflicts. The people in relation to this agency might not be called a State, but it would be like the State. The most that could be said for it is that it would exercise the functions of the present state in a more effective way with less accompanying abuses.

This discussion while centering about the objection to all use of coercion in law and administration as immoral extends much further. In showing how force should be used, the ends for which it should be used, we get a moral criterion for judging the state, and also get light thrown upon the problems connected with the historic evolution of the state. Historically it must be admitted that the state originated

$$
\text { [End page 7] }
$$


in violence and oppression, in conquest of one people by another usually and [in] the desire of the victorious people to hold the conquered in such subjection that they could exploit them. It must be admitted that the historic state has been conducted largely in the interests of an exploiting governing few, a reigning house or dynasty, or an economic class that could use political power to further its own interests. But it must also be admitted that political struggles have been waged against these conditions, and the political struggle for democratic government has been in the main an attempt to see that the state functioned in behalf of the public interest - that it legislates and administers in the interest of the people at large.

The other element in the criterion is that the operations of the state be as constructive as possible - that in its effects upon human nature its work be fostering, cultivating, rather than restrictive and choking, that it uses power to call out attention and thought rather than mere blind emotion, and that it stimulates publicity, communication, spread of ideas and enlightenment, instead of encouraging [illeg.], and the withholding of knowledge and skill.

For the long time in early modern thought political controversy centred about the worth of the state, being carried on by those who held that a limitation of the arbitrary power of the state was the most essential thing in England, and upon the continent by those who were impressed by the value of the state as a condition of social peace and order - the partisans of the liberal and limited state on one hand and of the absolute state on the other. While the former have been upon the whole successful in their desire to develop a government which should be representative of the public interest and responsible to the people, the latter have been largely successful in imposing their view of the state itself as sovereign and supreme, having no authority above it and owing no responsibility to anybody. In other words, the nationalist state has been gaining in

\section{[End page 8]}

power and dignity, while the action of legislators and administrators has been hedged about by more and more popular checks. Before considering the seeming contradiction presented by a state that is absolute while its organs of action - the government - are limited, we shall consider the two doctrines of the two schools of political thought.

[End page 9]

\section{Lecture XI [Chapter The Government, pp. 133-140]}

70 As was pointed out, the state is more than a people possessing a common territory; more even than a people a society, with a country and a common language, history, tradition and moral outlook. It implies a political organization also, an organization of the people for the purpose of exercising authority within and without, that is with respects to other peoples and countries, and also with respect to its own constituents. The organ, agency, instrumentality for the exercise of this authority is Government. The importance of the expression of the State through Government is so great that there is tendency to confuse the two. There is this much justification for the confusion that the problems of politics or the state become acute when they focus in problem of Government. The difference is 
clearly seen in such a fact as this: the sovereignty of the State is a commonplace of modern political thought; to restrict and define the powers of Government has been the chief political struggle of the least two or three centuries.

Put briefly the fundamental problem is this. The Government should be an organ of the general interest, an expression of the public will - that is, it should stand for and enforce the widespread interest that the whole society has in the acts of special groups or classes, because the consequences of these special acts ramify and affect others who have no direct concern - examples from family life, business corporation, contracts. Thus there is required an agency to formulate, express and execute the wider interest; to keep the activities of the various factors of the whole balanced and proportionate. Now this is a task of delicacy and complexity. For it deals with regulation of the indirect and remote consequences of acts - the public interest is not so immediate and conspicuous as the private. Is human wisdom equal to the task? But aside from this difficulty, the Government is itself composed of human beings having their own private interests, their own love of power and gain. Government is not an abstract idea,

\section{[End page 1]}

impersonal and transparent, but involves an aggregate of human beings with the same appetites and passions as their fellows. Is it then safe to clothe with power? Will not the fact that their power has a social and moral sanction only add to the ease and thoroughness with which they can use it for their own ends, or make the task of maintaining public order and security incidental to their own power, glory and enjoyment? Put in a less extreme form we get the problem which has controlled both the political theories and the political struggles of the Western world for three hundred years: How shall Government be constituted so that it shall adequately perform its legitimate function, that is [to] operate in the public interest, in behalf of the country as a whole, and not encourage the possessors of authority to employ it for their own special interests? How shall power enough be granted to fulfill the first task and yet that power be limited in its concrete exercise?

The problem consisted of two factors. One was historic. There was in existence Government by dynasties - that is, by families claiming superior birth and rank, patrimonial possession of the country, reigning by divine or some other unquestionable authority, and therefore not responsible to the people, responsible only to God - the absolutistic state in theory whether so exercised in practice or not. This was the particular historic background. The other factor is the standing one - a problem of human nature. Irresponsible power tends to arbitrary and selfish action. As Lincoln put it "No man is wise or good enough to govern other men without their consent." Expanded somewhat, "No matter how wise and good at the outset, wisdom and goodness deteriorate when combined with possession of irresponsible power over others." A Chinese scholar has acutely remarked that the European theory of responsible Government is based upon a belief in the inherent badness of men, and the consequent needs of checks even upon rulers. While the old Chinese theory was based upon faith in the intrinsic

[End page 2] 
goodness of human nature, the orderliness and loyalty of the subjects, the wisdom and benevolence of rulers. Hence the Confucian political philosophy really assumed the supremacy of moral forces, while the European philosophies - at least of the liberal school - have assumed the need of physical backing in order to prevent the immoral forces from becoming supreme. This raises a great problem, but it would be truer to state that the European theory is based not upon belief in the inherent badness of human nature, but that possession of unchecked power inevitably corrupts human nature - it becomes evil and foolish under such conditions. Another remark that may be made is that the increasing complexity and mobility of modern life has immensely increased the range of questions and affairs in which there is a public interest. Big association of labor and capital, growth of foreign and domestic commerce, selling goods at a distance, travel, transportation, telegraphs, doing business at a distance, migration and mobility of populations, has lessened the hold of local moral influences, those that come from subjection of an individual to the stead inspection and judgment of his own local and definite permanent group, while it has also increased the remoteness [of] scope and indirectness of consequences. Hence more public or political action is demanded than in a society that is continuing on old lines. The decay of customary control means an increase of legislative and administrative control. The channels in which moral forces operate change. Hence the absurdity of the plea sometimes heard - at least from foreigners - that while new methods of industry, commerce, finance etc. should be introduced into China, railways and factories etc., the old moral basis of social organization and government should be left intact. This is impossible, so there is no use of discussing its desirability. The mere effect of rapid and easy communication in making a population mobile means inevitably a lessening of the old family and neighborhood control and the

\section{[End page 3]}

need of new organs. The political problems of China today thus resemble in many respects those of Europe in the period of [the] most active transition, the seventeenth century - though complicated by an additional fact; the changes and experiments of Europe in the seventeenth century could go on without danger of interference from other nations which had already passed through the transitional stage of political organization into an integrated state.

73 We return then to a consideration of the various theories which have been evolved in Europe in connection with this problem of the development of a Government sufficiently powerful to maintain national security, peace and order remembering that each theory corresponds to some strong practical act. The first type of theory was generated in the disorder, strife and lawlessness attendant upon the break down of the authority of the Roman Church and Holy Roman Empire - the rise of independent states, development of trade, shifting from agricultural basis to industrial one. It said in effect that the importance of a strong single central power is so great in order to give men security of life and to enforce peace within and without, that no price is too great to pay - not even the surrender of all powers to the rulers of the state. Machiavelli, Hobbes and Spinoza on the theoretical side were the great names in this line of solution. State morality is of a different kind from private. The officers of the state when acting in behalf of the state are justified in acting upon a different moral basis [than] an individual. Without the central authority society would fly to pieces - would dissolve into anarchy and chaos, and no morality at all would be possible even were it desired by private individuals. No powerful 
government no state, no state no society, no society no stable human morals at all. So much is at stake therefore that rulers are justified in defense of the unity and power of the state to resort to fraud and violence to acts that are indefensible in private morality. This point was espec-

\section{[End page 4]}

ially [illeg.] by Machiavelli, who developed rules of statecraft - political maxims based on the end justifies the means, and since the end is supreme it justifies in case of emergency all and any means - expediency is the only rule. The Englishman Hobbes worked out a detailed scheme. According to him individuals left to themselves are forced into such conflict with one another that life becomes uncertain, property insecure - the natural state [is] a war of all against all, from fear of attack by others, from love of gain, and from desire for glory and honor - natural expressions of the fundamental psychological law of self-love. But there is also a natural law, urging men to self-preservation. This leads them to take the step which alone will make their lives secure - they all agree to surrender all their power into the hands of some authority. They divest themselves of all natural power and right. They agree to submit to the regulations of the Supreme power, the sovereignty thus created, keeping nothing back. Thus power because it is sovereign is responsible to nothing on earth, only to conscience and God. It may be republican oligarchical or monarchical in form. But its authority is unlimited by law or legal right. Expediency will tell the rulers not to push their power to the extreme. Wisdom will tell them to use it for the happiness of the whole people. But there can be no legal or political guarantees of such use of power. For the Government is the source of all law and politics, and hence cannot be under its own creatures. The only final check is moral practical - fear of revolution, fear that the people will repudiate the original contract they made. Spinoza developed under conditions of continental disorder and insecurity (similar to those in England in the first half of the seventeenth century) the germinal ideas of Machiavelli and Hobbes. It emphasized however more than either the moral necessity of the state as a condition of sociable relations among men and also the necessity of social relations to an individual for the development

\section{[End page 5]}

of his own personality, rational and therefore moral. Under the influence of social relations and intercourse alone, does the individual cease to be a creature of appetite and impulse making the private pleasure the measure of good and evil, and becomes a creature who has reason, that is a universal measure of good and evil. But only through the recognition of law, which is a product of political authority, does man emerge into the rational and moral estate. Spinoza, however, also held that while any form of government is preferable to no government (and therefore revolution is never justifiable) yet the republican form of Government is the ideal, and that in the degree in which humanity should, under the influence of law, become rational, would be the goal toward which the future evolutions of states would certainly tend. Meantime, more arbitrary kinds of governments were at least a school master to restrain the reign of appetite and passion in the masses and create the conditions for the education into rationality. In that sense every state, even the worst, is an expression of divine reason. The state rather than the church is the representative of God, the Absolute on earth. There is but one necessary 
moral limit to state action. Since it exists to make possible the evolution from a state of appetite to one of reason and law, it cannot encroach upon liberty of thought [and] liberty of reason without contradicting itself.

In some form or other the theory of the necessity of political organization to the existence of society, that is, of peaceful and orderly and mutual helpful human intercourse, became an axiom of all continental thought. Hence the power of the state is the foundation of morals, either actively or negatively a condition without which individuals could not be truly moral. Its importance is such that it must be absolute and irresponsible. France at the time of the revolution had been influenced by the liberal theory of England still

\section{[End page 6]}

to be discussed, and threw it over. But it remained for Europe, especially for German, modified by the form into which it was thrown by the German philosophers who made a synthesis of Spinoza with the political philosophy of Plato and Aristotle, according to which the state is the culmination of a manifestation of divine reason and will on the earth. It is superindividual and superhuman - an objectification in the form of time of the eternal purposes, meanings, Ideas, of God. The liberal philosophy, it was claimed, had gone into bankruptcy, committed suicide, in the excesses of the French Revolution, which had proclaimed the principle of individual liberty and rights. As against that the German theory of the State asserted the supremacy of the value and dignity of the state, which humanly speaking, could in essentials do nothing wrong in respect to its subjects, while in its contests with other states, victory was a God given sign of which had right on its side. As one state exhausts its mandate from Divine will, as revealed in its defeat, spiritual and moral domination, as well as political passes to another nation.

(See, German Philosophy and Politics) The political history of Europe cannot be understood without knowledge of the extent to which this view of the State as the foundation not only of secure material life but of secure moral life has influenced men's minds. Under the guise of idealistic philosophy and a progressive evolution of absolute purposes, Hegel reestablishes in a modernized form the exploded doctrine of [the] divine right of kings, and the rulers of Prussia made these conceptions the basis of an enlightened and in many ways benevolent despotism. The effect of the theory was double. On the one hand, it supplied a philosophic basis for autocracy, supported the practical demand for a strong army as the proper arm of the centralized state, and thus promoted militarism, and also fostered a conviction among the Germans that their Kultur was higher than that of other peoples, since they

\section{[End page 7]}

alone realized the ethical function and superhuman basis of the state. It gave a mystic quality to state activities which protected [illeg.] examination and criticism by the common citizen, and led to an identification of moral duty with submission to the direction of the state. But since in effect, the state is administered through a government, this mystic doctrine really maintained the supremacy of a certain class. To the credit of the philosophy must be put its stimulation of the conception of the state as a cultural agency, not simply [as] a tool of police order. According to it, individuals in isolation are 
incapable of coping with ignorance, want, destitution, poverty and misery. The state [through] government must foster art and science as well as promote education. It must not only protect individuals in their property but must make it possible for them to have and keep property. Hence a general system of insurance against sickness accident old age, unemployment etc. These things might be carried on by any modern state on the basis of some other political philosophy, but there is no doubt that the conception of the state as higher and deeper than society and the chief agency of moral existence made these activities easier of adoption and execution, and that the states which have been most influenced by the liberalistic philosophy - which we shall now discuss - were [illeg.] in their measures of social welfare under political authority, and that so far voluntary means, philanthropy etc., have not made good the deficit.

[End page 8]

\section{Lecture XII [Chapter Political Liberalism, pp. 141-146]}

The problem under discussion is the nature of the exercise of power by the state. How does power acquire moral validity, authority, how does it become right? The answer of the school whose theory was discussed at the last hour is in effect that the question is meaningless; that apart from the organization of social life which is termed the state, there are no such things as right and wrong effective among men. The state is the basis of the possibility of a genuine righteousness among men; without it men will live the life of appetite and passion, that is of brutes, even if of refined brutes; that the repressive and disciplinary side of the state, its political side, is incidental and secondary to its higher value in making rational action and concord based upon it possible. We come now to the theory which holds that the individuals live in society, live morally prior to political authority and that the existence of a power which restricts individual choice and action, that is liberty, is a real problem - that the state requires justification, and that there is but one way of justifying it. Government is just legitimate, has authority instead of brute power, only when it protects and secures rights that exist independently of it, in idea or even in time prior to its formation. John Locke was the first great spokesman of this political philosophy of liberalism. He wrote in effect to justify the political revolution of 1688 whereby the Stuart dynasty was expelled and a new dynasty under constitutional restrictions brought in. The so-called limited monarchy, or more correctly speaking, government which is under definite responsibilities to the people in the exercise of its powers. Locke like Hobbes believed that political society originated in a compact and derived its powers from that compact. But unlike Hobbes he didn't believe that man in the natural (pre-political state) was wholly selfish and egoistic and non-moral. He believed that he was a rational and social creature, recognizing his obligations to his fellows, and

\section{[End page 1]}

in the main inclined to act upon reasonably, rightly. But the state of nature had some great inconveniences. There was no one authorized to declare and promulgate the law of right intercourse with one's fellows; there was uncertainty and obscurity as to obligations. Moreover, in case of dispute or conflict there was no impartial judge, and no 
impartial executor of justice, no impartial redressor of wrongs. Each individual is likely to be prejudiced in judging his own case and to be passionate and unwise in securing his rights and rectifying his wrongs. Hence, sensible of these inconveniences, that is of the bad consequences of this condition, men met together, and agreed to surrender their right to judge and execute, to protect and redress by force their own rights. This they handed over to political authority to government which therefore came into existence as a funded or pooled power. But its powers were strictly limited by terms of the bargain or agreement that gave it existence. Its sole business is to promulgate the law, to judge of disputes between citizens and to secure fulfillment of its decisions. For these ends /sum total of the/ it has the powers of all citizens at command. And the citizens consent to this and agree to obey. But this power is limited to securing certain ends - the security of the life and property of the citizens. Men did not give up all their liberties for the sake of doing so; they gave up a few liberties in order to make the rest of their rights more certain and guaranteed. When the political authority (like that of the Stuarts) passes these bounds, and renders life and property insecure by arbitrary action, it is a usurper. It breaks the terms of the agreement upon which its power depends. Revolution under such circumstances is not illegal rebellion. It is merely a recognition by the people that the Government has abdicated its functions and is no longer a legitimate authority. In effect the people reserve the right to decide whether the Government is carrying out the purposes of the

\section{[End page 2]}

original contract.

Many persons have thought that the theory was exploded when it was shown that such compacts were not the historical origin of government, that they are purely mythological, historically speaking. But the fundamental idea is not touched thereby. Locke was not trying to account for the actual origin of governments. He was trying to account for the source of the rightful power of the government or political authority. And he found it in the use of this power to make the rights of individuals clear and explicit by promulgating laws, and to protect individuals in the surer and more constant exercise of their rights. Government exists for the sake of maintaining rights that exist in idea if not in historic time before it. The theory proclaimed the responsibility of all government to certain ends for the sake of which it exists, and the right of the citizens to determine whether the government is serving or destroying those ends. It brought the discussion of state affairs within the region of experience, out of the vague and mysterious air of divine rights and the superman, into the region of judgment and examination by commonsense tests of utility. It was in no sense a revolutionary theory except at crises of extreme misgovernment. It was but a check on possible excessive arbitrary action. It did not hold that in the [illeg.] of legitimate government the people were the actual holders of political power and authority. Locke was a monarchist not a republican, but a constitutional monarchist. The radical step was taken by Rousseau who was the philosopher of the French Revolution of 1789 as Locke was of that of 1688 in Great Britain. Rousseau held that there were no legitimate governments in existence, but that a just one might come into existence when all the people made a contract with one another - not with the government - to surrender all their private wills to a common will which should put the force of all individuals back of the rights and liberties of every member of society. The government is but a hired 
[End page 3]

servant to be engaged and dismissed at the will of the collective people for executing, carrying out its declared purpose. Thus the organized people are the sole repository of political power which they never surrender for any purpose. The only legitimate government is the democratic where the people as a body makes law - the legislative function being the prerogative of sovereignty because it declares the common will and interest. Thus the idea of popular sovereignty was extended from the original formation of political society and its spasmodic exercise in case of extreme misgovernment to the regular and constant maintenance of political activity. Only the democratic state is a legitimate form of state because the only one that solves the problem of reconciling individual liberty with the common good.

This doctrine while embodied more or less in the French Revolution did not take root in England where it was regarded as revolutionary as Bolshevism is today. In the early nineteenth century however Locke's liberalism was greatly modified by a new movement of thought, proceeding from leaders of the utilitarian school. Locke's theory was largely as [we] have seen negative in its practical workings out. It aimed at preventing extreme abuses in government. It was quite consistent with such an oligarchy as governed England till the Reform Bill of 1832 and later. The reformers of liberalism wanted positive guarantees that the Government would actually operate for the greatest good of the greatest number instead of in behalf of class interests - democratic in effect though not a pure democracy like Rousseau's in source. Their main ideas were (1) that each individual is the best judge of his own interests and welfare. Therefore there must be universal suffrage, so that the interest of each shall receive an equitable, fair expression. Everyone knows where the shoe pinches his own [foot], no one can possibly represent him in the primary expression of his desires. (2) [Members] of government, of the official class are individuals who left to themselves will pursue their own interests. There must be

\section{[End page 4]}

such measures as will make them identify their own interests with those of the people. Frequent and stated elections is the means. By having to render an account frequently, they will be made responsible to the people and find their own interest in serving their constituents - the idea of representative government. (3) Paradoxical as it sounds, the lawmakers must themselves be under [the] law and act according to it. There must be a fundamental law which shall determine not merely how judges and administrative officials shall act but which shall decide what the lawmakers shall and shall not do and how they may do it - a constitution.

(1) Popular suffrage, representative legislatures, parliaments, congresses, (2) responsibility to the electorate, and (3) constitutional government were thus the three great planks of the modern struggle for popular or republican government. The first plank was directed against the aristocratic notion that a wise selected class shall govern, on the ground that even the ignorant man knows his own wants and sufferings better than some one else. The second was aimed at securing legislation by orderly and public discussions of representatives of the people, directed against pure democracy on one hand - direct lawmaking by people - and against personal government by mandates and 
edits, pronouncements of officials on other. The third was directed to combining permanence and continuity in the state with fundamental guarantees of a political sort against abuse of power and with provision for regular change as conditions [of] change amendments to the fundamental or organic law. The end is well expressed in the words of American statesmen which however go back to Aristotle "in order that government should be a government of laws and not of men."

\section{[End page 5]}

80 In the various forms of liberal political philosophy we have the elements of political democracy set forth. These are: (1) The people are the source of political power, that is, authority to govern, to legislate and administrate proceeds from them, not from any superhuman force, not from a ruling dynasty or family, nor from a selected class. The idea of "Government by consent of the governed" seems like an inversion, a verbal paradox, but it conveys the idea that the people as a whole is the depository of power which in a certain sense it may be said only to delegate to the specific persons who govern. (2) The state exists for society, for promoting human intercourse, not society for the state. Rule, order, law and submission, are not valuable for their own sakes, but only for [the] sake of furthering of deepening and extending the processes of living together. The great error in the theories of liberalism is [that] they tended to make political organization a means of purely individual welfare, the rights of individuals conceived apart from the social ties and connections through which alone the individual can attain a full life (Hence reduction of happiness to pleasure in utilitarianism, and emphasis upon security, upon possession. Recognize state as tool of society and happiness will be seen to be found in establishing connections with others, and development to be more important than security). (2) The government is responsible to the people. It must be so organized as to render an account, to be liable to the people for the way in which it administers its affairs in the interest of the people. Suffrage, representative lawmaking bodies, a constitution, a distribution of powers among legislative executive, judiciary, so that each will not assume functions of others, the definition by law of the powers and limits of power of each official, provision for penalty the same as for private citizens - these things are not ends in themselves. They have no intrinsic sacredness. But they are the best devices yet invented for keeping officials responsible

$$
\text { [End page 6] }
$$

to the public will. These means are not perfect and will doubtless be improved. The extension of suffrage irrespective of sex, wealth or even education has been resorted to in order that an adequate expression of public will might be secured on one hand, and on the other that all persons might become interested in public affairs, might be sharing be awaken to recognition of their public responsibilities and abilities. Referendum and initiative are experiments in combining elements of pure democracy with representative.

The error in liberalism in thinking that the state originated in the choice of isolated individuals and aims to protect them as individuals in their rights resulted in two other errors. The first was in thinking of government as a kind of necessary evil, a surrender of some rights and liberties in order to be more certain of others - especially of physical existence and property (The especial possession of individual as such - see Locke). In fact 
the government is an organ or tool for the realization of public interests, the things that men have in common, that affect all in the way they work out, in their consequences. For example, roads, regular means of communication, schools, money, land coal, water supply. It does not follow of necessity that government must own these things, but it must see that they operate [and] function for general welfare [and] not for private gain. How this shall be accomplished is scientific rather than a moral matter - the end however is moral and positive, constructive. Private ownership can be tolerated only if upon the whole this is a better means of serving the universal interest. Jealously, distrust, suspicion of government has always come about as a survival of the dynastic, family, and superhuman state - formerly in Great Britain and US, now in Russia and Chine. This survival after the political organization has become democratic hampers the full use of the government as a democratic tool. It fosters private disregard of the public interest in social undertakings, economic and otherwise, the feel-

\section{[End page 7]}

ing that one business, one's affairs are his own private and exclusive concerns, that any public supervision or regulation is an impertinent interference, an encroachment upon proper personal liberty. This attitude tends not only to weaken government, to render it incompetent, but also tends to corruption - the strong private organizations, corporate cliques, militaristic or industrial, use governmental powers to promote their special interests at the expense of the public. The argument against extension of public activities, namely that government is both more corrupt and more incapable than private agencies, is largely due to two causes - one a survival of the non democratic government, the other the effect of an exaggeration of private activities.

The other great mistake of liberal philosophy was in supposing that the individual is an adequate judge of his own interest, and this self-interest of each may be counted upon to secure a regard for the net welfare of all. Modern society is so complex and so mobile, changing, that most measures of political activity, legislative and administrative are beyond the reach of judgment on the basis of personal interest. Loyalty to a group, a class, a country, a party, is more effective with most men than consideration for their self-interest - the latter is likely to lead either to abstinence from political activity, or to a corrupt employment of public agencies which prostitutes them to means of private gain and prestige. A public interest and public opinion rather than self-interest and judgment of what is to [be] the interests of the self must be the chief reliances of democratic government. This is why the attempt to introduce political democracy as a separate institution (that is suffrage, constitutions, parliaments etc.) has often failed. [It] will work on where there is a public, a civic conscience, where men are habituated to thinking as citizens, that is, as from the standpoint of the whole society and not from private or family or class standpoint, and where there is public opinion - that is means for popular discussion, exchange, com-

\section{[End page 8]}

munication. Physical things like telegraph, railways, letters, travel, newspapers, as well as rights of public meetings, rights of assembly, petition, publication are parts of the machinery of creation of a truly public opinion. 

collection of talkers. He made fun of the notion that by enactment following upon talking men could make laws - they might as well talk the multiplication-table into existence, he said. But experience shows that social laws, that is desirable regulations of conduct are not easy to discover, and that up to the present general discussion, speech back and forth is the best way hit upon to bring them to light. Mutual speech subjects ideas to criticism, improves them by selection and combination, leads to new thought and to inquiries. It brings to light hidden considerations, and broadens the range of ideas that influences action. In short, government tends to be at last resort by public opinion, and the only way to improve government is to improve public opinion by improving ideas and the methods of their circulation. Suffrage, chambers of deputies etc., are ultimately means of creating and expressing public opinion.

\section{Lecture XIV [Chapter Intellectual Freedom, pp. 173-180]} intellectual and ideal factors, and especially the dependence of the present crisis of the world upon shifting in intellectual authority and influence. Today we shall discuss the other aspect - the culmination of social institutions and arrangements in intellectual or ideal factors. Association is something quite different from mere herding together. Sheep crowd together for protection and warmth. Human beings associate in sharing ideas and experiences, in seeking ends seen to be common, in exchange of opinions and discoveries, in being loyal to the same persons and objects. The value of physical proximity and contact lies in the intercourse of affection, thought and action it makes possible. Culture, civilization measure the worth of social life, and civilization and culture are what they are because of ideal elements.

Put in a more specific form, the actual worth of any social arrangement lies in its educative effect: its release of thought, its nurture of the imagination, its refinement of emotions, in the persons who are influenced by it. It is for this reason that the act to think freely and the right to express thought in choosing beliefs, forms of worship and in free speech and publication are so important. Fear of ideas, intolerant suppression of thought and discussion is the common mark of every social tyranny. Distrust of the 
people, of human nature has nowhere been more marked than in the uniform endeavor of autocracy to limit freedom of conscience, inquiry, and publication. For the same reason the struggle towards democracy has always centred in the struggle to secure these rights. But the struggle of autocracy to limit thought and feeling to certain prescribed lines is not only aimed against the central thing in democracy, but it is aimed against civ-

\section{[End page 1]}

ilization itself for it is only through the development of thought, of knowledge, that civilization exists. The fight for freedom of thought, conscience, worship belief, speech, publication, discussion, is not merely a fight for personal freedom, but it is fight for all that distinguishes human society from an animal herd.

It is sometimes said that freedom of expression may be limited by external action, but not freedom of thought, since no outer power can make its way into inner consciousness. The statement is false. Whatever restricts freedom of expression limits and perverts freedom of mind. Mind lives only in communication, in give and take. It has to receive from others to be stimulated; it has to give out in order that its ideas may take form be rendered clear and articulate, coherent. Thought and language go together. Freedom of expression is a necessity not only that society may get the advantage of every individual's contribution, but in order that the individual may have anything worth expressing.

Only acts, however, can come directly within the notice of the public and its official representatives. Hence it is the act of speech, oral and written, that comes within the scope of legislation and the police. Constitutional governments all guarantee citizens the right of assembly, speech and publication. This does not mean that he [can] say anything he pleases with immunity from all punishment. If he incites others he is liable to punishment, just as when in the use of his liberty to free movement he trespasses upon the land of another or sets fire to a building he is liable to punishment. The individual has to take the risks of the way he uses his freedom. Two great reasons are supplied by experience for guaranteeing this freedom. The first is the safety vale argument. Speech is a mode of action, and when criticism and constructive suggestion are allowed in speech, this act prevents, this act prevents more

\section{[End page 2]}

violent and destructive acts. Secondly, there are two ways of government, coercion and persuasion. Without free speech, there is no opportunity for the use of persuasion, no possibility for formation of public opinion. The protection against foolish ideas is found in expression; not all people are foolish in the same way at the same time - opinions call out counter opinion, and in the mixture of discussion some light is shed, some advance in secure knowledge is made. No government however ever undertakes the suppression of all communication of ideas. Certain ideas which are orthodox, which are agreeable to social rulers are permitted and even encouraged. Only contrary ideas are prohibited. But this implies that no social changing is to be permitted, except by the way of terrorism and revolution. Without new ideas society would stagnate. The natural inertia of mind, the force of custom, is a sufficient check on rapid propagation of social changes without additional governmental action. At times new and dangerous ideas spread like an epidemic. But this is because of other conditions besides the ideas themselves. Men that 
are hungry and desperate will listen to anything that promises relief. It is the madness of despair that moves men rather than the ideas. Emotions, hope, revenge, not ideas are the real moving forces - as with the Bolsheviki. The remedy is not in suppressing ideas but in reforming the wrongs that breed the desperate willingness to believe anything that promises relief.

At the present time, that intellectual freedom which is the best safeguard of order as well as means of progress has a new enemy, in addition to the old one of direct suppression. It is propaganda, organized on a vast scale. This is more dangerous than censorship because it has the form of free speech. It poisons the sources of belief, the wells of truth. The war revealed its power. Government rests more and more upon persuasion and consent. Hence interested persons who have wealth or power try to control

\section{[End page 3]}

the organization and distribution of news, cables, writers, newspapers. The problem of the supply of intelligence required for proper actions can no longer be met merely by permitting individual freedom of speech and writing. There has to be a social organization of publicity in the interest of the public instead of some special class or country or government. There was never a time when real knowledge of what people all over the world are doing and thinking was so badly needed as at present, and upon the whole there hasn't been a time when this information was so perverted and distorted. However much men may rightly differ as to the wisdom of schemes of socialism and communism, all wise and sympathetic persons ought to agree upon the need of the widest possible sharing of knowledge, including news, the knowledge as to what is going on in society, in the whole society of humanity a communism of intelligence. Public and universal education is a social necessity in order to give a basis for this common sharing in knowledge and thought. But it cannot stop with school years. There must be means for continuing the education of all members of society about the things that concern society - its movements, problems, tendencies. In order that public opinion may control, there must be means of forming public opinion. In order that wise public opinion may control, the true facts must be gathered and disseminated by the press, by discussion. Private, local and class interest will govern men's actions until through the communication of knowledge the whole society, nay, the whole humanity, becomes spiritually one.

91 Common or like thoughts cannot in the present stage of the world be secured either by suppression or by direct inculcation, by trying to stamp one set of ideas on alike. Divergence of opinions is necessary for progress, and the only real unity is that which comes by exchange, based on toleration.

\section{[End page 4]}

Intellectual freedom is a true calculation of social life. In it individuality gets its best expression. Only where there is intellectual freedom can communication, the give and take of thought and feeling be full and varied. As we have seen before mere legal freedom to labor, move about, hold property etc., is incomplete unless at the same time men's minds are free to share in the meaning of what they do, free to take part in understanding the thoughts and plans that are expressed in industry and business. This activity of thought and emotion is distinctively human, and without it man lives on a 
non-human plane. Intellectual freedom thus depends on more than absence of restrictive laws. It depends upon positive factors and the legal right to free speech, free assembly, publication is important because without it these positive conditions get no good opportunity for expression. These positive conditions are first education which develops intellectual abilities and put the person in command of power to see, think and feel, and secondly opportunity to express thought in action not simply in words. Freedom of speech is precious, but it is not an end, only a means. To be able to put thought into operation in what we do and to find that what we do contributes to our life of thought and satisfactory sentiment and not merely to material products is the important thing. This ideal is manifested in the work of an artist and scientific man. The painter, the laboratory worker, is free to act upon his interest, to embody his thought. His limitations are due only to his ignorance, and lack of skill. Also what he does brings a return wave of thought and emotion back to him. He learns and gains intellectual skill through what he does. The tangible, material product is secondary to this intellectual enlargement and emotional enrichment. This basic problem of industrial society is to establish conditions that will place all men in their labor on the plane which the small class of scientists

[End page 5]

and artists now occupy. Then there will be a real consummation of social life in full freedom. There will [be] a true social democracy.

The same supremacy of mental factors is seen in the political side of social life. Carlyle made fun of popular government on the ground that it depends upon talking. It took the word Parliament from the French word parler as the object of his wit. He ridiculed the idea that by talking men could make social laws and more than they could make the laws of arithmetic by speech-making. Carlyle here showed an inability to appreciate the deepest thing in democracy. It is not that talking makes laws but that only through free and full communication, consultation, exchange, social conditions are discovered and the public interest and welfare are made clear and plain. What is needed is even more general participation in social discussion than we now have, an awakening of all the people to express their needs and desires and communicate to others their suggestions. The best value of the spread of suffrage, representative government etc. is that they promote this tendency. Every individual is a centre of conscious life, of happiness and suffering, of imagination and thought. This is the final principle upon which democracy rests. But this conscious life cannot be developed or realized except in association with others, interchange, flexible intercommunication. The relations of friends illustrates the meaning of this. If on the personal side, democracy means that all should have the opportunity for mental realization which artists and scientific men have, it also means that they shall be in the relations of free unobstructed intercourse with one another that friends are. Political democracy provides the machinery the form of this intercourse; it makes it possible. Education, companionship, the breaking down of class and family walls and barriers make it actual. 


\section{NOTES}

1. [In capital letters in the typescript.] 